\title{
Contaminant Levels in Eggs of American White Pelicans, Pelecanus erythrorhynchos, from Chase Lake, North Dakota
}

\author{
Pamela J. Pietz ${ }^{1}$, Marsha A. Sovada ${ }^{1}$, Christine M. Custer ${ }^{2}$, Thomas W. Custer ${ }^{2}$, \\ and KEVIN M. JOHNSON ${ }^{3}$
}

${ }^{1}$ U.S. Geological Survey, Northern Prairie Wildlife Research Center, $871137^{\text {th }}$ Street SE, Jamestown, North Dakota 58401 USA

${ }^{2}$ U.S. Geological Survey, Upper Midwest Environmental Sciences Center, 2630 Fanta Reed Road, La Crosse, Wisconsin 54603 USA

${ }^{3}$ U.S. Fish and Wildlife Service, Ecological Services, 3425 Miriam Avenue, Bismarck, North Dakota, 58501 USA

Pietz, Pamela J., Marsha A. Sovada, Christine M. Custer, Thomas W. Custer, and Kevin M. Johnson. 2008. Contaminant levels in eggs of American White Pelicans, Pelecanus erythrorhynchos, from Chase Lake, North Dakota. Canadian Field-Naturalist 122(4): 312-315.

\begin{abstract}
American White Pelicans (Pelecanus erythrorhynchos) are colonial nesters, making them susceptible to site-specific mortality factors. One of the largest known breeding colonies is at Chase Lake National Wildlife Refuge in North Dakota. In 2004, this colony suffered total reproductive failure. In 2005, we collected abandoned eggs from this colony to test for environmental contaminants. Nine eggs were analyzed for 28 organochlorine pesticides, total polychlorinated biphenyls, and 26 inorganic elements. Based on concentrations in this sample of eggs and levels linked to reproductive problems in birds, adult pelicans in the Chase Lake breeding colony are not at known risk from any of the environmental contaminants we measured.
\end{abstract}

Key Words: American White Pelicans, Pelecanus erythrorhynchos, eggs, organic contaminants, metals, Chase Lake National Wildlife Refuge, North Dakota.

American White Pelicans (Pelecanus erythrorhynchos, hereafter white pelicans) nest on the ground in colonies, often on remote islands. Because their breeding activities are spatially concentrated, they are vulnerable to site-specific mortality factors. Nearly half of the population breeds in a few colonies in the northern plains. One of the largest known nesting colonies is on Chase Lake National Wildlife Refuge (Sovada et al. 2005). In 2004, this colony suffered total reproductive failure following the mass exodus of breeding adults (Sovada et al. 2008). During the media storm precipitated by this event, numerous possible causes were proposed for the adult departures. Most of the suggestions were easily dismissed by a review of the available facts (Sovada et al. 2008), which suggested Coyote (Canis latrans) disturbance and a weather event were responsible. However, the attention provided impetus to examine some possibilities that, although highly unlikely, could not be entirely dismissed. Following the 2005 breeding season (another year in which extreme weather events severely reduced reproductive success [Sovada et al. 2008]), we salvaged eggs from the Chase Lake colony for contaminant testing.

White Pelicans eat mostly fish and other prey taken from shallow waters (Knopf and Evans 2004*). In the past, they have suffered direct effects from agricultural runoff (e.g., toxaphene poisoning [Johnson 1966]) and effects of bioaccumulated organic contaminants (e.g., eggshell thinning from DDT [Anderson et al. 1969; Anderson and Hickey 1972; Knopf and Street 1974]). Restrictions on use of some chemicals have reversed specific contaminant impacts (e.g., Bugden and Evans 1997), but white pelicans, like other piscivorous waterbirds, are still susceptible to a number of environmental contaminants. Several contaminants occur at different levels in male and female white pelicans, presumably because females can excrete organochlorines and some trace elements into their eggs prior to laying (Donaldson and Braune 1999). Thus, we tested contaminant levels in white pelican eggs as a surrogate for exposure levels in adult white pelicans.

\section{Methods}

During 11 to 18 August 2005, we collected 10 abandoned eggs, each from a different nest site, on the white pelican breeding colony at Chase Lake National Wildlife Refuge in Stutsman County, North Dakota. The salvaged eggs were laid during May or June 2005. Nine of the eggs were deemed suitable for analysis (one was cracked). In the laboratory, eggs were weighed on an electronic pan balance $(0.01 \mathrm{~g})$, measured (length $[0.01 \mathrm{~mm}]$ and width $[0.01 \mathrm{~mm}$, averaged 2 measurements taken at widest point]) with calipers, and the contents emptied into chemically clean glass jars. Egg samples were then frozen $\left(<-30^{\circ} \mathrm{C}\right)$ until chemically analyzed.

These nine eggs were analyzed for 28 organochlorine pesticides and total polychlorinated biphenyls (PCBs) by the Geochemical \& Environmental Research Group (GERG), Texas A\&M University, College Station, Texas. The same eggs were analyzed for 26 trace and other inorganic elements by the Trace Element 
Research Laboratory (TERL), Texas A\&M University, College Station, Texas.

Eggs were analyzed for the following organochlorine contaminants: aldrin; $\alpha-, \beta-, \gamma$ - and $\delta$-benzene hexachloride (BHC); $\alpha$ - and $\gamma$-chlordane; chlorpyrifos; cis-nonachlor; trans-nonachlor; dieldrin; endosulfan II; endrin; heptachlor; heptachlor epoxide (HE); hexachlorobenzene (HCB); mirex; oxychlordane; 1,1-dichloro-2-(o-chlorophenyl)-2-( $p$-chlorophenyl)ethane $\left[o, p^{\prime} \mathrm{DDD}\right] ; 1,1$-dichloro-2,2-bis( $p$-chlorophenyl) ethene [o, $p^{\prime}$-DDE]; 1,1,1-trichloro-2,2-bis( $p$-chlorophenyl) ethane $\left[o, p^{\prime}\right.$-DDT]; $p, p^{\prime}$-DDD; $p, p^{\prime}$-DDE; $p, p^{\prime}$-DDT; pentachloro-anisole; toxaphene; and 1,2,3,4- and 1,2,4,5-tetrachlorobenzene. Average levels of detection were $0.0008 \mu \mathrm{g} / \mathrm{g}$ wet weight for all organics except total PCBs and toxaphene, which had detection limits of $0.016 \mu \mathrm{g} / \mathrm{g}$ wet weight. For the above organic chemicals, tissues were homogenized and extracted with $\mathrm{Na}_{2} \mathrm{SO}_{4}$ and methylene chloride, and then purified by silica/alumina column chromatography and high performance liquid chromatography (MacLeod et al. 1985; Wade et al. 1988, Brooks et al. 1989). Quantitative analyses were performed by capillary gas chromatography with an electron capture detector for pesticides and PCBs.

Analyses were conducted for 21 inorganic elements, with detection limits (in $\mu \mathrm{g} / \mathrm{g}$ dry weight) given parenthetically as follows: aluminum (5), arsenic (0.1), boron (1), barium (0.1), beryllium (0.05), cadmium (0.01), chromium (0.5), cobalt (0.5), copper (0.5), iron (1), magnesium (1), manganese $(0.2)$, mercury $(0.002)$, molybdenum (1), nickel (0.5), lead (0.05), selenium $(0.1)$, strontium (0.05), titanium (0.5), vanadium (1), and zinc (0.5). Also analyzed were calcium (2), potassium (24), sodium (191), phosphorus (5), and sulfur (10).

For the inorganic analyses, tissue samples were homogenized and wet digested in the presence of nitric acid. Inductively coupled argon plasma spectrophotometry was used for all elements, except for arsenic, cadmium, lead, mercury, and selenium. Arsenic, cadmium, lead, and selenium were analyzed by inductively coupled plasma-mass spectroscopy and mercury by trapping on a gold column followed by atomic absorption.

For quality control purposes, each laboratory ran one blank, duplicate, and spike with the samples. Certified reference material was also used by each laboratory and one sample was confirmed by gas chromatography mass spectrometry. Concentrations were not corrected for percent recovery. The blanks, duplicates, and spikes met the respective GERG and TERL quality assurance standards. Concentrations of inorganic elements are reported on a dry weight basis. Organic contaminant concentrations were adjusted to account for moisture lost during incubation (Stickel et al. 1973) and after the nests were abandoned. The moisture correction factor for each egg was the total egg weight divided by the egg volume. Egg volume was estimated by the equation from Hoyt (1979): Volume $=0.51 * \mathrm{LB}^{2}$, where $\mathrm{L}$ is egg length and $\mathrm{B}$ is egg width (maximum diameter). All organic contaminant concentrations are expressed on a wet weight basis in tables and text. Average moisture and lipid content of the eggs are provided as percentages.

\section{Results}

Three organic chemicals, chlorpyrifos, $\delta$-BHC, and toxaphene, were not detected in our sample of white pelican eggs. Aldrin, $\alpha$ - and $\beta$-BHC, and $\gamma$-chlordane were each detected in $<50 \%$ of samples (Table 1 ) and had maximum concentrations of $\leq 0.002 \mu \mathrm{g} / \mathrm{g}$ wet weight. Of the remaining 23 organic chemicals all had geometric mean concentrations $<0.01 \mu \mathrm{g} / \mathrm{g}$ wet weight except for total PCBs $(0.35 \mu \mathrm{g} / \mathrm{g}), p, p^{\prime} \mathrm{DDD}(<0.02 \mu \mathrm{g} / \mathrm{g})$, $p, p^{\prime} \mathrm{DDE}(0.08 \mu \mathrm{g} / \mathrm{g})$, and dieldrin $(0.01 \mu \mathrm{g} / \mathrm{g})$ (Table $1)$. Moisture and lipid content of the eggs averaged $79.0 \%$ and $4.4 \%$, respectively.

Aluminum, boron, beryllium, cadmium, chromium, cobalt, molybdenum, nickel, titanium, and vanadium were not detected in our sample of white pelican eggs. Lead was detected in only 1 egg, which contained $<0.06 \mu \mathrm{g} / \mathrm{g}$ dry weight (Table 2). All of the remaining 15 elements were detected in all eggs (Table 2). Arsenic, mercury and selenium, which are of special interest because they can cause physiological problems in birds, had geometric mean concentrations of $0.28,0.69$, and $2.06 \mu \mathrm{g} / \mathrm{g}$ dry weight, respectively.

\section{Discussion}

Neither organic nor inorganic chemicals in white pelican eggs from the Chase Lake National Wildlife Refuge were at concentrations considered to be problematic for the health of the birds. For three organic chemicals that have been linked to reproductive problems, levels of concern reported for wild bird eggs are $>10 \mu \mathrm{g} / \mathrm{g}$ wet weight for PCBs (Hoffman et al. 1996; Custer et al. 2003), $>3 \mu \mathrm{g} / \mathrm{g}$ wet weight for $p, p^{\prime} \mathrm{DDE}$ (Blus et al. 1974), and $>9 \mu \mathrm{g} / \mathrm{g}$ wet weight for dieldrin (Peakall 1996). Geometric mean concentrations for these three contaminants in our samples were much lower: $<0.5 \mu \mathrm{g} / \mathrm{g}$ for PCBs, $<0.1 \mu \mathrm{g} / \mathrm{g}$ for $p, p^{\prime} \mathrm{DDE}$, and $<0.1$ for dieldrin. Compared to other locations, concentrations of $p, p^{\prime} \mathrm{DDE}$ at Chase Lake National Wildlife Refuge were lower than concentrations previously documented in white pelicans in California and Nevada (Boellstorff et al. 1985; Wiemeyer et al. 2005). Dieldrin and PCB concentrations were similar among these three studies and were low. Of the trace elements, arsenic, lead, mercury, and selenium can be problematic in wild birds, but they were at low concentrations in our sample of white pelican eggs. Only one egg had detectable concentrations of lead. Levels of concern in eggs for the other three elements are $>3 \mu \mathrm{g} / \mathrm{g}$ dry weight for arsenic (Seiler et al. 2003*), >2 $\mu \mathrm{g} / \mathrm{g}$ dry weight for mercury (Thompson 1996) and >12 $\mu \mathrm{g} / \mathrm{g}$ dry weight 
TABLE 1. Concentrations of organic contaminants in eggs $(n=9)$ of American White Pelicans nesting at Chase Lake National Wildlife Refuge, North Dakota, in 2005.

\begin{tabular}{|c|c|c|c|}
\hline Analyte & $\begin{array}{l}\text { Geometric mean } \\
\text { ( } \mu \mathrm{g} / \mathrm{g} \text { wet wt.) }\end{array}$ & $95 \%$ confidence interval & Range $^{\mathrm{b}}$ \\
\hline Aldrin & ${ }^{\mathrm{a}}$ & & $7 \mathrm{ND}-0.00169$ \\
\hline$\alpha-\mathrm{BHC}$ & - & & $8 \mathrm{ND}-0.000677$ \\
\hline$\beta$-BHC & - & & 6ND-0.00164 \\
\hline$\gamma$-BHC & 0.0009 & $0.0005-0.002$ & $3 \mathrm{ND}-0.00344$ \\
\hline$\alpha$-chlordane & 0.003 & $0.002-0.005$ & $1 \mathrm{ND}-0.00697$ \\
\hline$\gamma$-chlordane & - & & $5 \mathrm{ND}-0.00305$ \\
\hline$o, p^{\prime}-\mathrm{DDD}$ & 0.002 & $0.001-0.003$ & $1 \mathrm{ND}-0.00515$ \\
\hline$o, p^{\prime}-\mathrm{DDE}$ & 0.001 & $0.0006-0.001$ & $2 \mathrm{ND}-0.00193$ \\
\hline$o, p^{\prime}$-DDT & 0.001 & $0.0008-0.002$ & 1ND-0.00269 \\
\hline$o, p^{\prime}-\mathrm{DDD}$ & 0.015 & $0.011-0.019$ & $0.00858-0.0306$ \\
\hline$o, p^{\prime}-\mathrm{DDE}$ & 0.080 & $0.051-0.123$ & $0.0293-0.215$ \\
\hline$o, p^{\prime}$-DDT & 0.004 & $0.003-0.007$ & $0.00174-0.012$ \\
\hline Dieldrin & 0.013 & $0.009-0.019$ & $0.00528-0.0343$ \\
\hline Endosulfan II & 0.001 & $0.0006-0.002$ & 4ND- -0.00410 \\
\hline Endrin & 0.002 & $0.001-0.003$ & $0.000979-0.01009$ \\
\hline $\mathrm{HCB}$ & 0.001 & $0.0006-0.001$ & 2ND- -0.00305 \\
\hline Heptachlor & 0.001 & $0.0007-0.002$ & 2ND-0.00544 \\
\hline Heptachlor epoxide & 0.003 & $0.002-0.003$ & $0.00164-0.00385$ \\
\hline Mirex & 0.002 & $0.0007-0.003$ & 3ND- 0.00559 \\
\hline cis-nonachlor & 0.003 & $0.001-0.005$ & 1ND-0.00773 \\
\hline trans-nonachlor & 0.006 & $0.005-0.009$ & $0.00308-0.0139$ \\
\hline Oxychlordane & 0.003 & $0.003-0.005$ & $0.00182-0.00694$ \\
\hline PCBs (total) & 0.354 & $0.298-0.419$ & $0.243-0.496$ \\
\hline Pentachloro-anisole & 0.002 & $0.001-0.002$ & $0.00101-0.00299$ \\
\hline $1,2,3,4$-tetrachlorobenzene & 0.001 & $0.0006-0.002$ & 3ND-0.00511 \\
\hline $1,2,4,5$-tetrachlorobenzene & 0.001 & $0.0006-0.002$ & $3 \mathrm{ND}-0.00394$ \\
\hline
\end{tabular}

a Geometric mean not calculated because $<50 \%$ of samples with detectable concentrations.

b The number before 'ND' is the number of samples that had undetected values.

TABLE 2. Element concentrations in eggs $(n=9)$ of American White Pelicans nesting at Chase Lake National Wildlife Refuge, North Dakota, in 2005.

\begin{tabular}{lccc}
\hline \hline Analyte & Geometric mean $(\mu \mathrm{g} / \mathrm{g}$, dry wt. $)$ & $95 \%$ confidence interval & Range \\
\hline Arsenic & 0.282 & $0.238-0.334$ & $0.16-0.384$ \\
Barium & 0.693 & $0.474-1.01$ & $0.229-1.75$ \\
Calcium & 6621 & $5007-8754$ & $2940-10900$ \\
Copper & 7.19 & $6.41-8.07$ & $5.74-9.67$ \\
Iron & 77.5 & $57.5-104$ & $27.6-124$ \\
Lead & $-\mathrm{a}$ & & $8 \mathrm{ND}^{\mathrm{b}}-0.058$ \\
Magnesium & 633.7 & $572-702$ & $539-837$ \\
Manganese & 0.709 & $0.527-0.953$ & $0.344-1.73$ \\
Mercury & 0.685 & $0.55-0.85$ & $0.457-1.19$ \\
Phosphorus & 4595 & $3839-5500$ & $2530-6080$ \\
Potassium & 6051 & $5347-6847$ & $3780-7150$ \\
Selenium & 2.06 & $1.79-2.37$ & $1.53-3.26$ \\
Sodium & 9401 & $8510-10384$ & $6780-11000$ \\
Strontium & 8.64 & $6.06-12.3$ & $3.61-15.5$ \\
Sulfur & 6787 & $6518-7068$ & $6180-7680$ \\
Zinc & 37.7 & $35.8-39.8$ & $33.1-41.5$ \\
\hline \hline
\end{tabular}

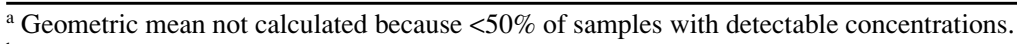

b The number before 'ND' is the number of samples that had undetected values.

for selenium (Heinz 1996). None of the concentrations in our sample of white pelican eggs approached these levels of concern. Concentrations of mercury in pelican eggs at Chase Lake NWR were 2-4 times lower than in Nevada and California from areas with known mercury contamination (Wiemeyer et al. 2007). Based on concentrations of organic and inorganic contaminants in this sample of eggs, adult white pelicans in this breeding colony are not at risk from any of the environmental contaminants measured. 


\section{Acknowledgments}

Funding for chemical analyses was provided by the Environmental Contaminants Program of the U.S. Fish and Wildlife Service. We thank Michael Erickson and Paulette Scherr, U.S. Fish and Wildlife Service, for logistic support; Paul Dummer for sample processing and statistical analysis; and Kevin Kenow, Mark Sherfy, A. J. Erskine, and two anonymous reviewers for helpful comments on the manuscript.

Document Cited (marked * in text)

Knopf, F. L., and R. M. Evans. 2004. American White Pelican (Pelecanus erythrorhynchos), in The birds of North America online. Edited by A. Poole. Cornell Lab of Ornithology, Ithaca. http://bna.birds.cornell.edu/bna/species/057.

Seiler, R. L., J. P. Skorupa, D. L. Naftz, and T. Nolan. 2003. Irrigation-induced contamination of water, sediment, and biota in the western United States - synthesis of data from the National Irrigation Water Quality Program. U.S. Geological Survey Professional Paper 1655, Version 1.1. http:// pubs.water.usgs.gov/pro1655.

\section{Literature Cited}

Anderson, D. W., and J. J. Hickey. 1972. Eggshell changes in certain North American birds. Pages 514-540 in Proceedings of the XVth International Ornithological Congress. Edited by K. H. Voous. E. J. Brill, Leiden, The Netherlands.

Anderson, D. W., J. J. Hickey, R. W. Risebrough, D. F. Hughes, and R. E. Christensen. 1969. Significance of chlorinated hydrocarbon residues in breeding pelicans and cormorants. Canadian Field-Naturalist 83: 91-112.

Blus, L. J., N. S. Neely Jr., A. A. Belisle, and R. M. Prouty. 1974. Organochlorine residues in Brown Pelican eggs: relation to reproductive success. Environmental Pollution 7: 81-91.

Boellstorff, D. E., H. M. Ohlendorf, D. W. Anderson, E. J. O'Neill, J. O. Keith, and R. M. Prouty. 1985. Organochlorine chemical residues in white pelicans and Western Grebes from the Klamath Basin, California. Archives of Environmental Contamination and Toxicology 14: 485493.

Brooks, J. M., T. L. Wade, E. L. Atlas, M. C. Kennicutt II, B. J. Presley, R. R. Fay, E. N. Powell, and G. Wolff. 1989. Analysis of bivalves and sediments for organic chemicals and trace elements. Third Annual Report for NOAA's National Status and Trends Program, Contract 50-DGNC-500262. Washington, D.C.

Bugden, S. C., and R. M. Evans. 1997. Egg composition and post-DDT eggshell thickness of the American White Pelican, Pelecanus erythrorhynchos. Canadian FieldNaturalist 111: 234-237.

Custer, C. M., T. W. Custer, P. M. Dummer, and K. L. Munney. 2003. Exposure and effects of chemical contaminants on Tree Swallows nesting along the Housatonic River, Berkshire County, Massachusetts, USA, 1998-2000. Environmental Toxicology and Chemistry 22: 1605-1621.

Donaldson, G. M., and B. M. Braune. 1999. Sex-related levels of selenium, heavy metals, and organochlorine compounds in American White Pelicans (Pelecanus erythrorhynchos). Archives of Environmental Contamination and Toxicology 37: 110-114.
Heinz, G. H. 1996. Selenium in birds. Pages 447-458 in Environmental contaminants in wildlife: interpreting tissue concentrations. Edited by W. N. Beyer, G. H. Heinz, and A. W. Redmon-Norwood. CRC/Lewis Publishers, Boca Raton, Florida.

Hoffman, D. J., C. P. Rice, and T. J. Kubiak. 1996. PCBs and dioxins in birds. Pages 165-207 in Environmental contaminants in wildlife: interpreting tissue concentrations. Edited by W. N. Beyer, G. H. Heinz, and A. W. RedmonNorwood. CRC/Lewis Publishers, Boca Raton, Florida.

Hoyt, D. F. 1979. Practical methods of estimating volume and fresh weight of bird eggs. Auk 96: 73-77.

Johnson, J. W. 1966. White Pelican die-off at Cavour Lake. South Dakota Bird Notes 18: 57.

Knopf, F. L., and J. C. Street. 1974. Insecticide residues in White Pelican eggs from Utah. Wilson Bulletin 86: 428434.

MacLeod, W. D., D. W. Brown, A. J. Friedman, D. G. Burrow, O. Maynes, R. W. Pearce, C. A. Wigren, and R. G. Bogar. 1985. Standard analytical procedures of the NOAA National Analytical Facility 1985-1986. Extractable toxic organic compounds. Second edition. U.S. Dept. of Commerce, NOAA/NMFS, NOAA Technical Memorandum, NMFS F/NWRC-92, Washington, D.C.

Peakall, D. B. 1996. Dieldrin and other cyclodience pesticides in wildlife. Pages 73-97 in Environmental contaminants in wildlife: interpreting tissue concentrations. Edited by W. N. Beyer, G. H. Heinz, and A. W. Redmon-Norwood. CRC/Lewis Publishers, Boca Raton, Florida.

Sovada, M. A., D. T. King, M. Erickson, and C. Gray. 2005. Historic and current status of the American White Pelican breeding at Chase Lake National Wildlife Refuge, North Dakota. Waterbirds 28 (Special Publication 1): 27-34.

Sovada, M. A., P. J. Pietz, K. A. Converse, D. T. King, E. K. Hofmeister, P. R. Scherr, and H. S. Ip. 2008. Impact of West Nile virus and other mortality factors on American White Pelicans at breeding colonies in the northern plains of North America. Biological Conservation 141: 10211031.

Stickel, L. F., S. N. Wiemeyer, and L. J. Blus. 1973. Pesticide residues in eggs of wild birds: adjustment for loss of moisture and lipid. Bulletin of Environmental Contamination and Toxicology 9: 193-196.

Thompson, D. R. 1996. Mercury in birds and terrestrial mammals. Pages 341-356 in Environmental contaminants in wildlife: interpreting tissue concentrations. Edited by W. N. Beyer, G. H. Heinz, and A. W. Redmon-Norwood. CRC/ Lewis Publishers, Boca Raton, Florida.

Wade, T. L., E. L. Atlas, J. M. Brooks, M. C. Kennicutt II, R. G. Fox, J. Sericano, B. Garcia, and D. DeFreitas. 1988. NOAA Gulf of Mexico Status and Trends Program: Trace organic contaminant distribution in sediments and oysters. Estuaries 11: 171-179.

Wiemeyer, S. N., J. F. Miesner, P. L. Tuttle, and E. C. Murphy. 2005. Organochlorine contaminants in the American White Pelican breeding at Pyramid Lake, Nevada. Waterbirds 28 (Special Publication 1): 95-101.

Wiemeyer, S. N., J. F. Miesner, P. L. Tuttle, E. C. Murphy, L. Sileo, and D. Withers. 2007. Mercury and selenium in American White Pelicans breeding at Pyramid Lake, Nevada. Waterbirds 30: 284-295. 